E-ISSN: 2798-0960 P-ISSN: 2798-0987

Volume 2 Nomor 1 - Juni 2021

\title{
PENGARUH MODEL PEMBELAJARAN COOPERATIVE SCRIPT BERBANTU MEDIA BONEKA TANGAN BERSERI TERHADAP KETRAMPILAN BERBICARA SISWA
}

\author{
Ika Sang Hidayatul Hijriah \\ ikasang11@gmail.com \\ Program Studi Pendidikan Guru Sekolah Dasar \\ Fakultas Keguruan dan Ilmu Pendidikan \\ Universitas Muhammadiyah Magelang \\ Magelang
}

\begin{abstract}
This study aimed to determine the effect of cooperative script learning model assisted by serial hand puppet media on the speaking skills of fourth grade students in Kedungumpul Village. The research was experimental research with the type of pre-experimental design. The samples taken for this study were 16 fourth grade students, whereas the sampling technique used is purposive sampling. The data were collected by using performance method which were then analyzed by using nonparametric statistical methods, namely the Wilcoxon test with the help of the SPSS version 25 program. The results showed that the cooperative script model assisted by serial hand puppet media had an effect on the speaking skills of fourth grade students in Kedungumpul Village. This is evidenced by the Wilcoxon test results obtained which is Asymp. Sig. (2-tailed) worth 0.000. The results of the pretest and posttest scores increased in average values, from 47.00 in the pretest value to 61.31 in the posttest value. The value 0.000 is less than 0.05 . This means that the cooperative script learning model assisted by serial hand puppet media has an effect on students' speaking skills.
\end{abstract}

Keywords: cooperative script, hand puppet series, speaking skills

\section{PENDAHULUAN}

Bahasa merupakan salah satu bagian terpenting dalam kehidupan bermasyarakat. Penggunaan bahasa yang baik menunjukkan jati diri masyarakat yang baik. Untuk dapat menggunakan bahasa yang baik, seseorang harus memiliki kemampuan berbahasa yang baik pula. Kemampuan berbahasa tidak muncul dengan sendirinya, namun merupakan sebuah proses, sehingga membutuhkan waktu dan usaha untuk mencapainya. Kemampuan berbahasa akan memudahkan setiap orang untuk berkomunikasi dengan orang lain, karena kemampuan berbahasa sering juga disebut sebagai kemampuan berkomunikasi. Kemampuan berkomunikasi dapat dikategorikan berdasarkan aspekaspek kemampuan bahasa yaitu: menyimak atau mendengarkan, berbicara, membaca dan menulis.

Salah satu aspek yang menjadi tolok ukur kemampuan berbahasa yaitu berbicara. Berbicara merupakan salah satu bentuk komunikasi dalam berbahasa. Ketrampilan berbicara merupakan suatu kemampuan yang dimiliki seseorang untuk menyampaikan gagasan, pikirannya atau perasaan sehingga gagasan-gagasan tersebut dapat dipahami orang lain. Ketrampilan berbicara sangat banyak manfaatnya bagi siswa, di antaranya adalah dapat memperbanyak kosakata yang dikuasai siswa, melatih siswa untuk berani mengekspresikan apa yang dirasakan dan dialaminya, dan dapat melatih siswa untuk menggunakan bahasa Indonesia yang baik dan benar. Ketrampilan berbicara juga dapat membentuk generasi muda yang kreatif, berani, percaya diri, dan mampu menggunakan ujaran yang komunikatif, jelas, sistematis, dan mudah dipahami. 
Salah satu model pembelajaran yang bisa mendukung proses belajar bahasa Indonesia serta dapat melatih ketrampilan berbicara siswa adalah model pembelajaran cooperative script. Model pembelajaran cooperative script merupakan penyampaian materi ajar yang diawali dengan pemberian wacana atau ringkasan materi ajar kepada siswa. Menurut Huda (2011), model pembelajaran cooperative script adalah model belajar yang membuat siswa bekerja secara berpasangan dan secara lisan mengikhtisarkan atau mengungkapkan bagian-bagian dari pokok bahasan materi yang telah dipelajarinya. Pada model pembelajaran ini, siswa akan dipasangkan dengan temannya kemudian berperan sebagai pembicara dan pendengar. Pembicara menyampaikan materi yang sudah disimpulkan dan pendengar akan menyimak, mengoreksi, dan menunjukkan ide-ide pokok.

Salah satu media pembelajaran yang bisa digunakan untuk membantu proses pembelajaran bahasa Indonesia, terutama untuk ketrampilan berbicara siswa, adalah media boneka tangan berseri. Media boneka tangan berseri ini bisa dijadikan pilihan dalam pembelajaran ketrampilan berbicara karena akan mendorong siswa untuk mengungkapkan ide atau bahan cerita, sekaligus menumbuhkan keberanian, meningkatkan penguasaan bahasa, dan memperkaya ekspresi. Menurut Daryanto (2011), boneka tangan adalah benda tiruan dari bentuk manusia atau binatang yang dimainkan dengan satu tangan. Boneka tangan sebagai media cerita memiliki banyak kelebihan, diantaranya adalah dapat menarik minat dan perhatian siswa dalam pembelajaran serta dapat melibatkan siswa secara aktif dalam permainan sandiwara boneka. Selain itu, siswa juga termotivasi untuk berimprovisasi, baik dari segi kebahasaan maupun nonkebahasaan, sehingga siswa menjadi trampil berbicara dengan menampilkan karakter atau tokoh tertentu sesuai dengan keinginan dan kemampuannya (Mariana \& Zubaidah, 2015). Boneka tangan berseri dapat menjadi media untuk membantu siswa agar berani berekspresi atau mengungkapkan perasaan dan gagasannya. Di samping itu, boneka tangan juga bisa mendorong tumbuhnya fantasi atau imajinasi siswa. Penggunaan media boneka tangan berseri dapat menjadi alternatif sekaligus inovasi bagi guru dalam menumbuhkan keberanian dan meningkatkan ketrampilan siswa dalam berbicara.

\section{Tinjauan Pustaka}

Penelitian ini relevan dengan beberapa penelitian sebelumnya yang membahas mengenai model pembelajaran cooperative script, media pembelajaran boneka tangan dan ketrampilan berbicara siswa. Penelitian yang pertama dilakukan oleh Yani (2019) dengan judul Peningkatan Ketrampilan Berbicara Melalui Model Pembelajaran Cooperative Script pada Mata Pelajaran Bahasa Indonesia Siswa Kelas V SDN Cibuntu o5 Kabupaten Bekasi. Hasil penelitian ini menunjukkan bahwa model cooperative script dapat meningkatkan ketrampilan berbicara siswa pada mata pelajaran Bahasa Indonesia yang terlihat pada setiap siklusnya. Hasil ketrampilan berbicara siswa pada siklus I menunjukkan persentase kelulusan sebesar 54,17\% dengan rata-rata nilai 69,37. Di siklus II hasilnya meningkat menjadi 70,83\% dengan rata-rata nilai 78,75. Kemudian di siklus III, ketrampilan berbicara siswa meningkat lagi menjadi 83,33\% dengan rata-rata nilai 87,50.Persamaan penelitian Yani (2019) dengan penelitian yang dilakukan penulis adalah keduanya sama-sama menggunakan model pembelajaran cooperative script untuk meningkatkan ketrampilan berbicara siswa dalam mata pelajaran Bahasa Indonesia. Sedangkan perbedaannya terletak pada jenis, subjek, dan tempat penelitian. Jenis penelitian yang digunakan dalam penelitian di atas adalah penelitian tindakan kelas (PTK) dengan subjek siswa kelas V SDN Cibuntu o5 Kabupaten Bekasi. Sementara penelitian ini berupa penelitian kuantitatif dengan subjek siswa kelas IV dan mengambil tempat di Desa Kedungumpul.

Penelitian serupa dilakukan oleh Pratiwi (2016) dengan judul Penggunaan Model Cooperative Script untuk Meningkatkan Kemampuan Menyimak Siswa Kelas V SDN Bulak 1 Bendo Magetan. Hasil penelitian ini menunjukkan bahwa model Cooperative Script mampu meningkatkan kemampuan menyimak siswa. Hal ini ditunjukkan dengan peningkatan nilai evaluai siswa. Pada pra-tindakan nilai rata-rata kelas hanya 62. 
Kemudian, pada siklus I, nilai rata-rata kelas meningkat menjadi 75,5. Begitu pula pada siklus II nilai rata-rata kelas bertambah lagi menjadi 89. Persamaan penelitian Pratiwi (2016) ini dengan penelitian yang dilakukan penulis adalah sama-sama menggunakan model cooperative script pada materi bahasa Indonesia, sedangkan perbedaannya terletak pada ketrampilan berbahasa yang dijadikan sasaran dan jenis penelitian. Ketrampilan berbahasa yang ditekankan pada penelitian ini adalah kemampuan menyimak sedangkan pada penelitian penulis adalah ketrampilan berbicara. Selain itu, jenis penelitian ini adalah penelitian tindakan kelas, sedangkan jenis penelitian yang dilakukan penulis adalah penelitian kuantitatif.

Penelitian lainnya dilakukan oleh Widowati (2016) dengan judul Pengaruh Media Boneka Tangan Terhadap Ketrampilan Menyimak Cerita Kelas IIB SDN Margoyasan. Hasil penelitian menunjukkan bahwa media boneka tangan berpengaruh pada ketrampilan menyimak cerita siswa. Hal ini ditunjukkan dengan nilai rata-rata ketrampilan menyimak cerita pada pretest sebesar 79,96 sedangkan pada posttest sebesar 88,79. Sehingga, selisih nilai rata-rata pretest dan posttest sebesar 8,83. Persamaan penelitian ini dengan penelitian yang dilakukan penulis adalah sama-sama menggunakan media boneka tangan dengan mata pelajaran bahasa Indonesia. Jenis penelitian juga sama-sama penelitian kuantitatif. Sementara itu, perbedaan keduanya terletak pada ketrampilan berbahasa. Ketrampilan berbahasa pada penelitian Widowati (2016) ini adalah kemampuan menyimak, sedangkan pada penelitian penulis ketrampilan berbicara.

\section{Landasan Teori}

Ketrampilan berbicara, menurut Hermawan (2014), adalah kemampuan mengungkapkan bunyi-bunyi artikulasi atau kata-kata untuk mengekspresikan pikiran berupa ide, pendapat, keinginan atau perasaan kepada mitra pembicara. Sementara itu, menurut Iskandarwassid \& Sunendar (2011), ketrampilan berbicara adalah ketrampilan mereproduksi arus sistem bunyi artikulasi untuk menyampaikan kehendak, kebutuhan perasaan dan keinginan kepada orang lain. Kesimpulan yang diperoleh berdasarkan beberapa pendapat di atas adalah ketrampilan berbicara merupakan ketrampilan yang dimiliki oleh seseorang dalam proses komunikasi dengan mengucapkan bunyi-bunyi artikulasi untuk menyampaikan pesan sehingga pesan tersebut dapat dipahami oleh orang lain. Supaya proses komunikasi mudah dipahami, maka kata yang diucapkan tentunya harus jelas dan lancar.

Model pembelajaran cooperative script menurut Huda (2011) adalah model belajar yang membuat siswa bekerja secara berpasangan dan secara lisan mengikhtisarkan atau mengungkapkan bagian-bagian dari pokok bahasan materi yang telah dipelajarinya dalam ruangan kelas. Aqib (2013) menyatakan bahwa dalam model pembelajaran cooperative script secara tidak langsung terdapat kontrak belajar antara guru dan siswa mengenai cara berkolaborasi. Kontrak belajar guru dan siswa adalah terjadinya kesepakatan antara guru dengan siswa, siswa dengan siswa untuk berkolaborasi dan memecahkan masalah dalam pembelajaran. Oleh karena itu, dapat disimpulkan bahwa dalam pembelajaran cooperative script terjadi kesepakatan dan kerjasama antara siswa dengan siswa dan siswa dengan guru tentang aturan-aturan dalam berkolaborasi dan mengungkapkannya secara lisan. Masalah yang dipecahkan bersama akan disimpulkan secara bersama-sama pula. Peran guru hanya sebagai fasilitator yang mengarahkan siswa untuk mencapai tujuan belajar. Interaksi belajar yang terjadi benar-benar interaksi antara siswa dengan siswa. Aktivitas siswa selama pembelajaran cooperative script dapat membantu mengembangkan pengetahuan dan ketrampilannya.

Menurut Daryanto (2011), boneka tangan adalah benda tiruan dari bentuk manusia, binatang atau tumbuhan yang dimainkan dengan satu tangan. Sementara menurut Sulianto dkk (2014), media boneka tangan adalah media pembelajaran yang digunakan oleh guru atau siswa dalam kegiatan pembelajaran yang terbuat dari potongan kain flanel, katun, kaos tangan, kaos kaki dan sebagainya dan dibentuk atau dihias sedemikian rupa sehingga dapat ditampilkan menjadi beraneka ragam tokoh 
dengan karakter masing-masing. Boneka tangan dapat berfungsi sebagai media pembelajaran yang digunakan untuk melibatkan anak ke dalam cerita yang sedang disampaikan, agar anak tersebut mampu menangkap isi pelajaran yang disampaikan oleh guru.

Secara lebih spesifik, media boneka tangan berseri merupakan media pembelajaran yang terbuat dari potongan kain, kemudian dibentuk sesuai dengan tokoh-tokoh dalam seri cerita rakyat. Cara memainkan media boneka tangan berseri sama dengan media boneka tangan lainnya, yaitu dengan memasukkan tangan ke dalam boneka tersebut dan digerakkan menggunakan jari tangan. Boneka tangan berseri dibuat berdasarkan tokoh seri cerita rakyat yang dipilih. Berbagai tokoh boneka tangan dalam cerita rakyat tersebut akan dimainkan guru maupun siswa dalam proses pembelajaran. Boneka tangan berseri semacam ini dapat dijadikan sebagai media pembelajaran untuk melatih dan meningkatkan ketrampilan berbicara siswa dengan cara bercerita. Penggunaan media boneka tangan berdasarkan tokoh-tokoh seri cerita rakyat akan menarik perhatian siswa dan memotivasi siswa untuk mengikuti pembelajaran secara aktif.

\section{Metode Penelitian}

Penelitian ini dilaksanakan di Desa Kedungumpul pada siswa kelas IV dengan sampel sebanyak 16 siswa. Pengambilan sampel dalam penelitian ini dilakukan dengan teknik purposive sampling, yaitu teknik penentuan sampel dengan pertimbangan tertentu (Sugiyono 2016). Penelitian ini menggunakan metode eksperimen dengan jenis preeksperimental design. Menurut Sugiyono (2016), penelitian eksperimen adalah metode uji coba yang ditujukan untuk mencari pengaruh perlakuan tertentu terhadap yang lain dalam kondisi yang dikendalikan. Selanjutnya, desain penelitian ini berbentuk one group pretest-posttest. Untuk lebih jelasnya, desain penelitian ini dapat dilihat pada Diagram.

\begin{tabular}{lll}
\hline O1 & $\mathrm{X}$ & $\mathrm{O} 2$ \\
\hline
\end{tabular}

Diagram: One Group Pretest-Posttest Design

Keterangan:

O1 : Nilai pretest (sebelum diberikan model pembelajaran cooperativescriptberbantuan media boneka tangan berseri)

$\mathrm{X}$ : Pemberian perlakuan dengan model pembelajaran cooperative scriptberbantuan media boneka tangan berseri

O2 : Nilai posttest (sesudah diberikan model pembelajaran cooperative scriptberbantuan media boneka tangan berseri)

Pada penelitian ini terdapat dua variabel, yakni variabel bebas dan variabel terikat. Variabel bebas dalam penelitian ini adalah model cooperative script berbantu media boneka tangan berseri, sedangkan variabel terikatnya berupa ketrampilan berbicara. Metode pengumpulan data dilakukan dengan unjuk kerja. Unjuk kerja ini dilakukan untuk mengetahui sejauh mana ketrampilan berbicara siswa dalam pembelajaran melalui kegiatan bercerita. Aspek penilaian ketrampilan berbicara pada penelitian ini terdiri dari aspek pelafalan, pilihan kata, kelancaran berbicara, penguasaan topik, dan kekomunikatifan (kemudahan untuk dipahami). Kemudian, perangkat pembelajaran dan instrumen yang digunakan dalam penelitian ini meliputi silabus, rencana pelaksanaan pembelajaran (RPP), soal pretest dan posttest, lembar penilaian ketrampilan berbicara, materi ajar, media pembelajaran, dan lembar kerja siswa.

Analisis data pada penelitian ini berupa uji hipotesis dengan analisis nonparametrik dengan menggunakan uji Wilcoxon. Hal ini karena sampel yang dipilih kurang dari 30, data yang diperoleh berbentuk ordinal, dan sampel dipilih tidak secara random (Sunjoyo dkk. 2013). Uji Wilcoxon ditujukan untuk mengetahui perbedaan 
signifikan pengukuran awal (pretest) dan pengukuran akhir (posttest) tentang ketrampilan berbicara. Adapun perhitungan dengan rumus Wilcoxon dilakukan dengan menggunakkan SPSS versi 25. Menurut Santoso (2012), data dikatakan mengalami perbedaan yang signifikan apabila sig < 0,05. Jika sig < 0,05 maka Ho ditolak dan Ha diterima. Jika sig > 0,05 maka Ho diterima dan Ha ditolak.

\section{HASIL DAN PEMBAHASAN}

Dari pengumpulan data ketrampilan berbicara pada siswa kelas IV di Desa Kedungumpul dengan materi cerita rakyat, diperoleh hasil analisis data dalam bentuk uji hipotesis. Ketrampilan berbicara siswa ditunjukkan dengan nilai per-aspek ketika pretest dan posttest. Data hasil pretest dan posttest ketrampilan berbicara siswa dapat dilihat pada Tabel 1.

Tabel 1: Kategori Nilai Pretest dan Posttest Ketrampilan Berbicara

\begin{tabular}{lccc}
\hline \multirow{2}{*}{ Kategori } & \multirow{2}{*}{ Rentang } & \multicolumn{2}{c}{ Nilai } \\
\cline { 3 - 4 } & & Pretest & Posttest \\
\hline Sangat Baik & $65-80$ & 0 & 7 \\
Baik & $50-64$ & 7 & 8 \\
Cukup & $35-49$ & 6 & 1 \\
Kurang & $20-34$ & 3 & 0 \\
\hline
\end{tabular}

Tabel 2: Nilai Minimal, Maksimal, dan Rata-rata Ketrampilan Berbicara

\begin{tabular}{cccc}
\hline Kategori & $\begin{array}{c}\text { Nilai } \\
\text { Minimal }\end{array}$ & $\begin{array}{c}\text { Nilai } \\
\text { Maksimal }\end{array}$ & Rata-rata \\
\hline Pretest & 30 & 62 & 47,00 \\
Posttest & 39 & 72 & 61,31 \\
\hline
\end{tabular}

Berdasarkan Tabel 1 dan Tabel 2, dapat dikatakan bahwa ada perubahan nilai dari pretest ke posttest. Perubahan ini dapat dilihat pada rata-rata nilai, yakni 47,00 pada pretest, menjadi 61,31 pada posttest. Kategori dan rentang nilai yang diperoleh pada pretest dan posttest juga berbeda. Pada pretest, tidak ada siswa yang mendapatkan nilai dengan kategori sangat baik dengan rentang 65-80, sedangkan posttest terdapat 7 siswa yang mendapatkan nilai dengan kategori ini. Kemudian, pada pretest terdapat 3 siswa yang mendapatkan kategori nilai kurang dengan range 20-34, sedangkan pada posttest tidak ada siswa yang mendapatkan nilai pada kategori yang sama. Sementara itu, hasil pretest dan posttest untuk rata-rata per-aspek dapat dilihat pada Tabel 3 .

Tabel 3: Nilai Rata-rata Pretest Aspek Ketrampilan Berbicara

\begin{tabular}{lcc}
\hline \multirow{2}{*}{\multicolumn{1}{c}{ Aspek }} & \multicolumn{2}{c}{ Rata-rata } \\
\cline { 2 - 3 } & Pretest & Posttest \\
\hline Pelafalan & 45,25 & 60,88 \\
Pilihan Kata & 46,81 & 58,88 \\
Kelancaran Berbicara & 41,38 & 56,88 \\
Penguasaan Topik & 54,25 & 66,63 \\
Kekomunikatifan & 47,25 & 60,94 \\
\hline
\end{tabular}

Dari Tabel 3 terlihat bahwa seluruh aspek ketrampilan berbicara siswa, mulai dari pelafalan, pilihan kata, kelancaran berbicara, penguasaan topik hingga kekomunikatifan, menunjukkan adanya peningkatan. Beberapa tabel hasil pretest dan posttest di atas, dapat diringkas sebagaimana tampak pada Grafik 1. 


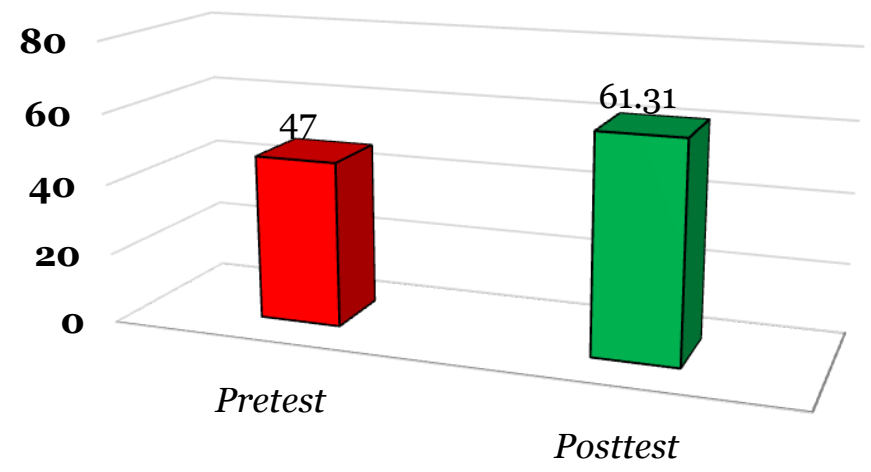

Grafik 1: Nilai Rata-rata Pretest dan Posttest

Dilihat dari pengukuran akhir (posttest) ketrampilan berbicara, diketahui bahwa rata-rata ketrampilan berbicara siswa setelah diberikan perlakuan (treatment), lebih tinggi dibandingkan sebelum diberikan treatment atau pretest. Grafik 2 menunjukkan hasil perbandingan penilaian setiap aspek pada pengukuran awal dan pengukuran akhir ketrampilan berbicara.

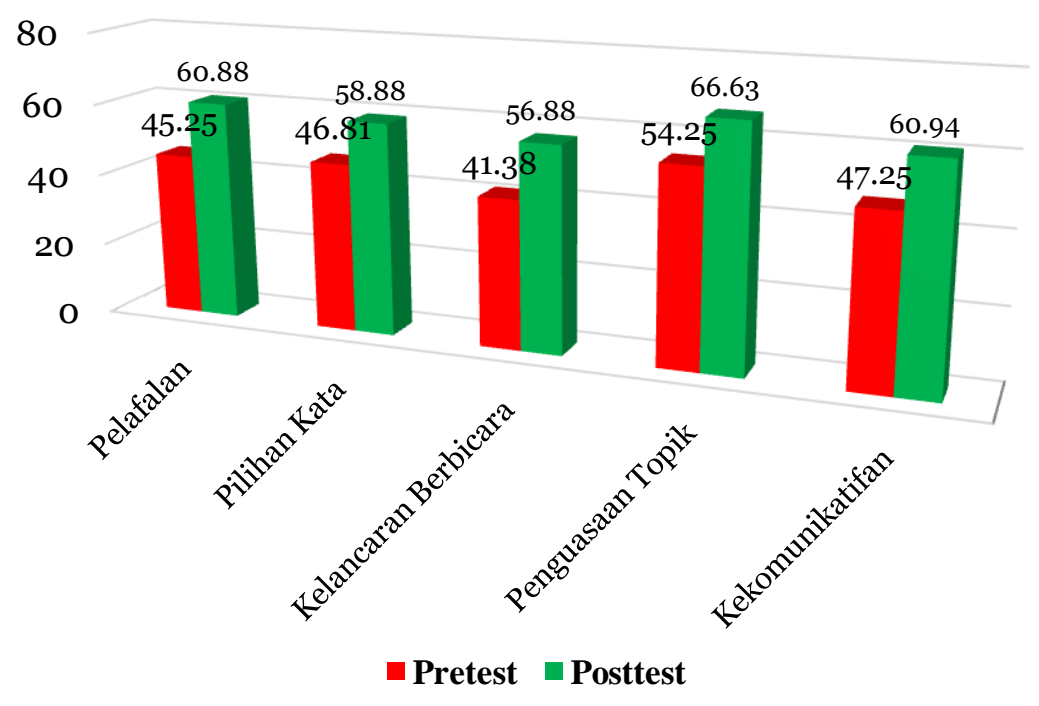

Grafik 2: Perbandingan Rata-rata Per-Aspek

Berikut penjelasan Grafik 2 di atas:

1. Pelafalan, dari hasil pretest diperoleh nilai rata-rata 45,25 dengan kategori cukup, sedangkan dari hasil posttest diperoleh nilai rata-rata 60,88 dengan kategori baik.

2. Pilihan kata, dari hasil pretest diperoleh nilai rata-rata 46,81 dengan kategori cukup, sedangkan dari hasil posttest diperoleh nilai rata-rata 58,88 dengan kategori baik.

3. Kelancaran berbicara, dari hasil pretest diperoleh nilai rata-rata 41,38 dengan kategori cukup, sedangkan dari hasil posttest diperoleh nilai rata-rata 56,88 dengan kategori baik.

4. Penguasaan topik, dari hasil pretest diperoleh nilai rata-rata 54,25 dengan kategori baik, sedangkan dari hasil posttest diperoleh nilai rata-rata 66,63 dengan kategori sangat baik. 
5. Kekomunikatifan, dari hasil pretest diperoleh nilai rata-rata 47,25 dengan kategori cukup, sedangkan dari hasil posttest diperoleh nilai rata-rata 60,94 dengan kategori baik.

Dilihat dari tabel dan grafik di atas, tampak jelas perbandingan ketrampilan berbicara subjek antara sebelum dan sesudah diberikan treatment dengan menggunakan model pembelajaran cooperative script berbantu media boneka tangan berseri. Dari segi hasil, terjadi peningkatan ketrampilan berbicara. Setiap subjek mengalami peningkatan yang berbeda-beda. Ada subjek yang mengalami peningkatan sangat tinggi, sedang, dan ada yang rendah. Hal ini disebabkan karena karakteristik pribadi setiap subjek berbedabeda. Demikian pula dalam hal penerimaan materi.

Setelah diketahui hasil pretest dan posttest, proses selanjutnya adalah analisis data statistik hasil uji pretest dan posttest tersebut. Metode analisis data yang digunakan dalam penelitian ini adalah statistik non-parametrik dengan uji Wilcoxon. Uji Wilcoxon digunakan untuk menganalisis hasil dari dua data berpasangan apakah berbeda atau tidak. Dalam hal ini, peneliti bermaksud mengetahui pengaruh model pembelajaran cooperative script berbantu media boneka tangan berseri terhadap ketrampilan berbicara. Tabel 4 menunjukkan hasil uji analisis data statistik yang diolah menggunakan SPSS versi 25.

Tabel 4: Wilcoxon Signed Ranks Test

\begin{tabular}{lcrcc}
\hline \multicolumn{1}{c}{ Tests } & Ranks & N & Mean Rank & Sum of Ranks \\
\hline \multirow{3}{*}{ Posttest- } & Negative Ranks & $\mathrm{O}^{\mathrm{a}}$ & .00 & .00 \\
Pretest & Positive Ranks & $16^{\mathrm{b}}$ & 8.50 & 136.00 \\
& Ties & $\mathrm{O}^{\mathrm{c}}$ & & \\
& Total & 16 & & \\
\hline
\end{tabular}

Pada Tabel 6, terlihat bahwa negative ranks = o baik itu pada nilai $\mathrm{N}$, mean rank maupun sum of ranks. Hal ini menunjukkan tidak adanya penurunan dari nilai pretest ke nilai posttest. Selanjutnya, positive ranks pada $\mathrm{N}=16$ membuktikan bahwa semua subjek mengalami peningkatan dalam ketrampilan berbicara. Ini diperkuat dengan nilai mean rank sebesar 8.50 dan sum of ranks sebesar 136.00. Sementara itu, pada ties didapatkan nilai o yang artinya tidak ada nilai yang sama antara pretest dan posttest.

Tabel 5: Test Statistics ${ }^{a}$

\begin{tabular}{cc}
\hline Result & Posttest-Pretest \\
\hline Z & $-3.517^{\mathrm{b}}$ \\
Asymp. Sig. (2-tailed) & 0,000 \\
\hline
\end{tabular}

Tabel 5 memperlihatkan tes statistik dari output SPSS. Di sini terlihat bahwa Asymp. Sig. (2-tailed) bernilai 0,000. Nilai o,ooo lebih kecil dari o,05. Berdasarkan pengambilan keputusan, bahwa data dikatakan mengalami perbedaan yang signifikan apabila sig < 0,05. Dengan melihat hasil ini, maka Ho ditolak dan Ha diterima. Ha pada penelitian ini adalah model cooperative script berbantu media boneka tangan berseri berpengaruh terhadap ketrampilan berbicara.

Kelebihan penelitian ini di antaranya adalah para siswa dapat bekerja sama dengan teman kelompoknya dalam kegiatan pembelajaran. Selain itu, mereka juga mau mengikuti kegiatan pembelajaran dengan aktif, antusias, dan bahkan mampu menjelaskan pendapatnya. Namun penelitian ini juga memiliki kekurangan yang terjadi pada pertemuan pertama, yaitu siswa sulit untuk diajak berperan aktif dalam pembelajaran dan beberapa di antaranya malah asyik bermain sendiri pada saat proses pembelajaran sedang berlangsung. 


\section{Kesimpulan}

Hasil penelitian ini menunjukkan bahwa model pembelajaran cooperative script berbantu media boneka tangan berseri berpengaruh positif terhadap ketrampilan berbicara pada siswa kelas IV di Desa Kedungumpul. Hal ini dibuktikan dengan hasil uji hipotesis Asymp. Sig. (2-tailed) yang bernilai o,ooo. Nilai o,o0o ini lebih kecil atau kurang dari 0,05, seingga Ho ditolak dan Ha diterima. Selain itu, pengaruh penggunaan media boneka berseri terhadap ketrampilan berbicara siswa juga terlihat pada peningkatan nilai posttest (pengukuran akhir). Rata-rata nilai pretest adalah 47.00 dengan nilai minimum 30 dan nilai maximum 62, sedangkan rata-rata nilai posttest adalah sebesar 61.31 dengan nilai terendah 39 dan tertinggi 72.

Hasil penelitian ini dapat dijadikan sebagai bahan pertimbangan dalam pelaksanaan kegiatan pembelajaran, baik penggunaan model pembelajaran cooperative script maupun penggunaan media boneka tangan berseri untuk meningkatkan ketrampilan berbicara siswa. Selain itu, sekolah juga bisa mengembangkan model cooperative script dan mengkreasi media boneka tangan berseri dari berbagai tokoh cerita, sehingga kegiatan pembelajaran dapat berjalan secara aktif terutama yang berkaitan dengan ketrampilan berbicara.

\section{DAFTAR PUSTAKA}

Aqib, Zainal. 2013. Model-model, Media, dan Strategi Pembelajaran Kontekstual (Inovatif). Bandung: Yrama Widya

Daryanto. 2011. Media Pembelajaran. Bandung: Sarana Tutorial Nurani Sejahtera

Hermawan, Acep. 2014. Metodologi Pembelajaran Bahasa Arab. Bandung: Remaja Rosdakarya

Huda, Miftahul. 2011. Cooperative Learning Metode, Teknik, Struktur, dan Model Penerapan. Yogyakarta: Pustaka Belajar

Iskandarwassid \& Dadang Sunendar. 2011. Strategi Pembelajaran Bahasa. Bandung: Remaja Rosdakarya

Pratiwi, Putri Cerianing. 2016. "Penggunaan Model Cooperative Script untuk Meningkatkan Kemampuan Menyimak Siswa Kelas V SDN Bulak 1 Bendo Magetan.” Jurnal Metamorfosa 4 (1): 82-92

Mariana, Siti. \& Enny Zubaidah. 2015. "Pengaruh Penggunaan Media Boneka Tangan Terhadap Ketrampilan Bercerita Siswa Kelas V SD Se-gugus 4 Kecamatan Bantul.” Jurnal Prima Edukasia 3 (2): 166-176

Santoso, Singgih. 2012. Panduan Lengkap SPSS Versi 20. Jakarta: PT Elex Media Komputindo

Sugiyono. 2016. Metode Penelitian Kuantitatif-Kualitatif dan R \& D. Bandung: Alfabeta

Sulianto, Joko, Asri Fita Mei Untari \& Fitri Yulianti. 2014. "Media Boneka Tangan dalam Metode Bercerita untuk Menanamkan Karakter Positif kepada Siswa Sekolah Dasar." Jurnal Pendidika 15 (2): 94-104

Sunjoyo, Rony Setiawan, Verani Carolina, Nonie Magdalena \& Albert Kurniawan. 2013. Aplikasi SPSS untuk SMART Riset. Bandung: Alfabeta

Widowati, Diah Ayu. 2016. "Pengaruh Media Boneka Tangan Terhadap Ketrampilan Menyimak Cerita Kelas II B SD Negeri Margoyasan.” Jurnal Ilmiah PGSD Universitas Negeri Yogyakarta 27 (5): 580-586

Yani, Indri. 2019."Peningkatan Ketrampilan Berbicara Melalui Model Pembelajaran Cooperative Script pada Mata Pelajaran Bahasa Indonesia Siswa Kelas V SDN Cibuntu o5 Bekasi Kabupaten Bekasi." Jurnal Pedagogik Pendidikan Sekolah Dasar 7 (2): 29-35 